\title{
Functions of Translanguaging Performed by Korean-American Emergent Bilinguals
}

\author{
Chaehyun Lee \\ Department of Educational Instruction and Learning, Southeastern Oklahoma State University, Durant, USA \\ Email address: \\ clee@se.edu \\ To cite this article: \\ Chaehyun Lee. Functions of Translanguaging Performed by Korean-American Emergent Bilinguals. International Journal of Elementary \\ Education. Vol. 9, No. 3, 2020, pp. 50-59. doi: 10.11648/j.ijeedu.20200903.11
}

Received: July 30, 2020; Accepted: August 13, 2020; Published: September 8, 2020

\begin{abstract}
In this article, I employed a qualitative discourse analysis method from a heteroglossic perspective to investigate first-grade Korean American bilingual students' translanguaging practices in a Korean heritage language (HL) school. Although the instruction was delivered exclusively in Korean in the HL classroom, the students were allowed to use English and translanguage if they needed. The transcripts of audio-recordings of students' spoken language were the main resources for this qualitative study. I first examined the incidence of the students' translanguaging. In performing the analysis of translanguaging function, I adopted Jakobson's [1] six functions of language (directive, expressive, referential, phatic, metalinguistic, and poetic). The findings showed that the function of students' translanguaging was documented in the five following categories: referential, directive, expressive, metalinguistic, and poetic. The close analysis revealed that 14 different subsidiary functions were further discovered under the five functional categories. The functional analysis of the students' translanguaging performance indicates that their translanguaging was not accidental or deficient, but they were sophisticated, systematic, and purposeful. The findings imply that engaging in translanguaging when communicating even in a monoglossic classroom setting (such as an HL classroom) is considered as a natural phenomenon among bilingual students as they were activating and developing their bilingualism through everyday translanguaging practices. The article provides implications for teachers of bilingual learners.
\end{abstract}

Keywords: Bilingual Education, Korean Bilinguals, Heritage Language Learning, Translanguaging, Heteroglossia, Discourse Analysis

\section{Introduction}

In the past, bilingual educators believed that bilinguals' languages should be kept separate in learning and teaching so that emergent bilingual students were provided with appropriate amounts of instruction in the target languages, and the mixing of languages should not be allowed in the classroom setting [2]. As a result, research with emergent bilingual children was conducted from a monoglossic perspective, in which bilinguals were viewed as developing competence in two separate languages since "[they] are expected to be and do with each of their languages the same thing as monolinguals" [3]. Accordingly, researchers who investigated emergent bilingual children's language use often analyzed their use of each language independently of each other [4].

Recently, a heteroglossic paradigm for viewing and conducting research on bilingualism has emerged. Heteroglossia refers to bilinguals' use of multiple languages when they draw from their integrated and unitary linguistic resources to communicate and construct meaning $[5,6]$. García [5] called the heteroglossic practices that bilinguals utilized across their languages, "translanguaging." The heteroglossia perspective allows speakers to utilize their full language repertoires and collective linguistic resources to achieve their communicative aims in a given situation [7], and translanguaging opens up the spaces to accept and appreciate all kinds of multimodal languaging practices [6]. Accordingly, an increasing number of researchers have examined bilingual students' translanguaging practices by investigating how they incorporate their full language repertoires $[8,9]$.

Yet, most of the translanguaging research was conducted in dual-language classrooms $[10,11]$, where teachers 
encouraged their students to learn and speak in two languages, which might have prompted the students' translanguaging. Little is known about bilingual students' translanguaging practices in other types of classroom settings, such as, heritage language (HL) schools. Furthermore, research on bilingual students' language use and translanguaguging practices has primarily focused on the Spanish-English bilingual group to date; thus, we have little understanding about translanguaging practices of other L1 speakers, especially those from non-related ancestral languages, such as Korean and English [12]. In order to narrow the gaps in the current literature, the present study aims to investigate translanguaging practices by KoreanEnglish emergent bilingual students in a Korean HL classroom. The following research question guided my inquiry:

What are the functions of translanguaging used by KoreanAmerican bilingual students in a heritage language classroom?

\section{Theoretical Framework}

\subsection{Translanguaging Paradigm from a Heteroglossic Perspective}

Bakhtin [13] coined the term heteroglossia to explain speakers' simultaneous use of a diverse range of registers, voices, languages, or codes in their daily lives and authors' use of multiple voices in written texts. Because Bakhtin [13] was interested in explaining how languages are shaped by social, historical, and political influences, his term heteroglossia describes the existence of and relationship between different language varieties. Bakhtin's notion of heteroglossia explains how language use involves various socio-ideological languages and the coexistence of different ideological viewpoints.

Recently, researchers have adopted the Bakhtinian notion of heteroglossia to investigate bilingual students' employment of two or more languages $[6,14]$ by using the term "translanguaging." According to García [5], translanguaging refers to bilingual speakers' normal and natural practices that they engage in the dynamic and flexible use of their two or more languages to communicate, construct meaning, and transmit knowledge $[15,16]$. Unlike traditional bilingual classrooms, where teachers only use the target language during instruction, translanguaging emphasizes bilingual teachers' and students' fluid utilization of their linguistic repertoires to communicate, comprehend, and learn. Translanguaging rejects the view of bilinguals as "two monolinguals in one body" [17], and instruction in two monoglossic contexts. García and Wei [8] warned that "bilingual students' linguistic repertoires should not be measured with a single construct in a standard language" (p. 133). Other researchers also recommended that bilingual students should be given the opportunity to use their entire linguistic repertoires to make meaning and to develop their biliteracy skills [18].

\subsection{Theoretical Framework to Identify Translanguaging Functions}

To identify the functions that characterized the firstgraders' oral translanguaging, I designed a theoretical framework, which primarily drew from Jakobson's [1] six communicative functions of language-referential, conative, emotive, phatic, metalingual, and poetic. According to Appel and Muysken [19], language switching that carries a referential function mostly occurs when there is a lack of knowledge in the target language. Thus, bilingual speakers tend to switch languages when they do not know particular words or phrases in the language spoken. Grosjean [20] pointed out this as "the phenomenon of the most available word" (p. 125), which saves bilingual speakers time and effort to find the exact word in the current language spoken. Thus, switches for referential function involves when certain concepts and expressions are not available in the target language. In addition, referential function of switching occurs when the speaker engages in language alternations to convey the intended meanings accurately and to deliver habitual expressions (such as greetings, thanking, and apologies) [21].

The directive function of switching occurs when a speaker wants to direct someone by requesting or persuading [19]. This function is used to include or exclude a person or group of people from a conversation by choosing a language that is (or is not) familiar to the listeners. Accordingly, the directive function helps listeners to become more engaged in conversation and to build intimate relationships [22]. In the same sense, the directive function helps speakers to draw the listeners' attentions [21]. Language switching that carries the expressive function suggests that speakers switch their languages to express emotions and feelings (e.g., happiness, anger, sadness). In addition, speakers engage in language alternations as they express or empower their identities as bi/multilinguals [23].

A bilingual's language alternation for the metalinguistic function is used when the speaker needs to clarify and check whether s/he uses the same code as the listener [19]. Gort [24] pointed out that that metalinguistic switching occurs when speakers compare and contrast two languages or comment on unique features of languages. According to Gort, metalinguistic switching provides speakers the tool to monitor their own language use. Moreover, the metalinguistic function of switching occurs when speakers include similes or metaphors to create vivid imagery, which helps them explain an idea or make a comparison. The phatic function of switching occurs when the speaker alternates languages to emphasize parts of a conversation by changing his/her tone, which is considered as important [19]. According to Tribus [25], the primary purpose of phatic switching is to establish, prolong, or discontinue the conversation; hence, the phatic function of switching relates to "the connection between speakers rather than the transmission of information" (p. 17). Lastly, the poetic function of switching occurs when the bilingual speakers switch languages to make jokes and use 
funny phrases by adding a sense of humor for entertainment and amusement purposes [19]. Tribus [25] pointed out that the poetic function is known as the aesthetic function because its primary focus is "the beauty of the language itself" (p. 25).

\section{Methods}

I employed the constructivist/interpretive research paradigm [26], with its focus on social construction because I wanted to understand the everyday translanguaging practices that the first graders naturally displayed from their everyday experiences. I utilized qualitative discourse analysis [27] to identify the functions for their translanguaging and the contextual factors that appeared to influence their translanguaging. Discourse analysis helped me to carefully examine what the students did with Korean and English and how they used languages within specific events. Qualitative, open-ended, semi-structured interviews with the students provided information about their perceptions on their language use, and how and why they translanguaged. This study aimed to examine English dominant Korean-English bilingual students' translanguaging practices from a heteroglossic perspective, taking into account how they translanguaged for varied functions and how their translanguaging prompt their engagement in learning Korean.

\subsection{Research Context}

The study was conducted in a first-grade classroom at a Korean HL school (K-5) in a midwestern university town for 14 weeks of the spring semester. Less than $70 \%$ of the town population identified as non-Latinx white, $13 \%$ as Asian, and $15 \%$ as foreign-born. There were no Korean-English bilingual education schools in the local school districts. Thus, the Korean language school was designed for Korean students in the town to help their HL learning by providing formal instruction in Korean at each grade level. The school was private, and Korean parents in the town funded the Korean HL school for their children to develop their HL learning. Approximately 100 students enrolled in the school each year, with 5-10 students in each class. During the school year, Korean children attended the HL school on Saturdays for three hours, from 10:20 a.m. to 1:20 p.m.

\subsection{Participants}

This article focused on three of the five first graders who attended the first-grade HL class at the Korean HL school. I received parental permission and student assent for four of the five students; thus, I excluded the student for whom parental permission was not granted. I also excluded one student, who identified herself as Korean dominant and did not use English nor translanguaging when speaking. During the interview with each student before the data collection for the study, the three participating students (Mino, Jina, and Bomi; pseudonyms were used for all the participants) reported that they preferred to speak English when participating in the class discussions. They rated their English proficiency higher than their Korean proficiency and identified themselves as English dominant. The three students were born in the U. S. and received all-English instruction at U. S. elementary schools during the school week. Two of the three students (Mino and Jina) had attended the Korean HL school since preschool, while Bomi had attended the school since kindergarten. The students and their families spent one month each year visiting relatives in Korea.

I was the first-grade teacher at the Korean HL school. It was in my fifth year of teaching first graders at the school. I am from South Korea, a native-Korean speaker, and bilingual in Korean and English. I have a Ph. D. in bilingual/ESL education and have employed qualitative methods and discourse analysis in other research studies.

\subsection{Data Collection Sources and Procedures}

Classroom instruction and language use. The school day in the first-grade classroom consisted of three parts. The first part (50 minutes) was designed to develop the students' communicative skills (speaking and listening skills) in Korean by using a government-designated Korean textbook. During this period, the teacher spoke in Korean and expected the students to use Korean. Then, the students had recess for 15-20 minutes, when they freely used English and translanguage. After recess, the class participated in Korean book reading and in-class writing for 50 minutes each for a total of 100 minutes. For the reading class sessions, the teacher brought a Korean picture book (e.g., folktales, fables) in a bilingual version, if available, to read with the students, and then held a book discussion with them. The students were allowed to use English and translanguaging if they needed, instead of being required to speak Korean only. Then, the class was given prompts to provide their written responses in Korean to the book. The data was collected during the storybook reading time and in-class recess when the students freely used English and translanguaging.

Audio-recording of students' spoken language. The students' talk during the book reading and discussion sessions were audio-recorded. Approximately 50 minutes of audiorecording for 14 weeks resulted in 700 minutes of classroom audio-recording. The students' talk during the in-door recess was audio-recorded for a total of 130 minutes.

Student interviews. I conducted two semi-structured and open-ended interviews (15-20 minutes each) with each student after class at the Korean HL school toward the beginning and end of the study. In the first interview, the students were asked ten questions about their language use at school and at home (with parents, grandparents, siblings), their language preference and proficiency, and ethnic identity. For the second interview, I brought key examples of each student's oral language data to the interview and asked specific questions about the data (e.g., Why did you use English here? Do you know the word in Korean?). During both interviews, I initially asked the questions in Korean, but the students were allowed to provide their answers in the 
language they preferred. Several informal interviews with the students (documented through retrospective fieldnotes or observation) occasionally occurred in the classroom. All the interviews were audio-recorded, and interviews that occurred in Korean were transcribed in Korean and later translated into English.

\subsection{Data Analysis}

The transcripts of audio-recordings were the main resources for this qualitative study. The students' oral language use was identified and analyzed with regard to the function of their translangauging. I first examined the incidence of the students' translanguaging, which occurred throughout data collection. Using Saville-Troike's [28] definition of communicative act, which refers to "coterminous [utterance] with a single interactional function" (p. 24), I analyzed each student's translanguaging incidence by looking at its occurrence within sentences (intrasentential) or between sentences (inter-sentential). I also paid attention to whether the students' translanguaging emerged from Korean to English or vice versa.

In performing the analysis of translanguaging function, I adopted Jakobson's [1] six functions of language (directive, expressive, referential, phatic, metalinguistic, and poetic) to identify the bilingual students' translanguaging. Based on Jakobson's six functional categories, I identified related categories that emerged from the students' translanguaging data and analyzed it with regard to the following five functional categories: referential, directive, expressive, metalinguistic, and poetic functions. A phatic function has not been reported in their translanguaging utterances, although it was detected when the students stayed in one language.

In order to find subsidiary functions of each observed translanguaging under the five categories, I focused on not only the students' language use but also the discourse contexts in which each translanguaging occurred, such as the topics of talk, the interlocutors as participants, the actions that the participants took, the purpose for communication. The interview with the students further helped me identify the reasons why they engaged in translanguaging practices. Eventually, 14 subsidiary functions were emerged under the five functional categories. Overall, I employed triangulation to address the research questions by investigating all the data (transcripts of audio-recordings, students interview results, classroom observations) to minimize misperception and the invalidity of my conclusions [29]. Agar [30] argued that "an isolated observation cannot be understood unless you understand its relationships to other aspects of the situation in which it occurred" (p. 125). I tried to have a holistic perspective when analyzing the data and discussing and reporting the results.

\section{Findings}

The students' oral language use data shows that all three students (Mino, Jina, and Bomi) employed their language repertoires both from Korean and English by engaging in translanguaging practices both at the word- and sentencelevels. The function of students' translanguaging was documented in the five following categories: referential, directive, expressive, metalinguistic, and poetic. Based on the five functional categories, I present a discourse analysis of the students' translanguaging examples to identify subsidiary functions of each documented translanguaging.

\subsection{Students' Translanguaging for Referential Function}

Throughout the students' translanguaging data, translanguaging for the referential function was recorded as the highest (616 out of 1012 utterances; $60.86 \%$ ) among the five functional categories. The students' translanguaging were analyzed as referential in the following four functions: (a) maintaining conversation/facilitating communication, (b) delivering accurate meanings of words/concepts, (c) elaborating one's ideas, and (d) Incorporating habitually used terms or referents.

$i$. Maintaining conversation/facilitating communication. The students' translanguaging often showed evidence that they borrowed lexical items from their dominant language (English) as they did not know the equivalent words in Korean. However, when they borrowed vocabulary knowledge from English through translanguaging, they were able to maintain their conversation without any deficiency in communication. Excerpt 1 shows an example by Jina when she inserted the English words "grain" and "protein" in her Korean utterance. During the student interview, I checked on whether Jina knew how to say the words that she spoke in English, but she admitted that she did not know the equivalent words in Korean. Instead, she provided the example of the food categories in Korean by stating, "rice and bread are types of grain" and "meat is a kind of protein." Her responses demonstrated her understanding of the food categories in Korean, which indicates that she merely did not know the referents to the words in Korean. Hence, Jina's English translanguaging for the unknown Korean words appeared to help her maintain a conversation and even facilitate her speech because she was able to deliver her messages without any interruption in her talk. (In the following Excerpts, English translations are provided within the brackets, and translanguaged words are underlined in the translations.)

Excerpt 1. Maintaining the conversation by translanguaging for unknown Korean words

Jina: ...나 배웠는데 grain 이랑 protein 많이 먹으면 좋아요. [...I learned that grain and protein are good for our health.]

ii. Delivering accurate meanings of words or concepts. There were times when the students employed translanguaging by borrowing the lexical items from English because there are no equivalent words or concepts in the Korean language. Excerpt 2 displays how Mino and Bomi inserted the English words while they were speaking in Korean. Mino added the word "sleepover" (line 1), and Bomi inserted the word "playdate" (line 2) in their Korean 
statements. Since there is no equivalent single noun for "sleepover" in Korean, and the concept of "playdate" does not exist in Korean, both Mino and Bomi utilized their English vocabulary knowledge as necessary while speaking in Korean. The examples display that Mino and Bomi's translanguaging helped them deliver accurate meanings of word and concept since the particular word and concept were not accessible in Korean.

Excerpt 2. Translanguaging for non-existing word and concept.

Mino: 나 어제 친구랑 sleepover 했는데 엄마가 맛있는 거 해줬어. [I did sleepover with my friend yesterday, and my mom made delicious food for us.]

Bomi: 난 어제 친구랑 playdate 했는데, 우리 무 신기한 거 만들었어. [I had playdate with my friend yesterday, and we made something interesting.

iii. Elaborating one's ideas. The students engaged in translanguaging when they elaborated on the concept of knowledge that they were explaining. Excerpt 3 illustrates how Jina engaged in a translanguaging strategy when she provided detailed information on a science concept. When the teacher asked the class about what they were learning during the science class in their American school (line 1), Jina responded in Korean that she had learned about the human body (line 2). In responding to the teacher's follow-up question about what she had particularly learned about the human body (line 3), Jina translanguaged entirely into English to provide the details (line 4). Since Jina had learned about the science concept in English, it might have been easier for her to use the same language when delivering the information. This particular example indicates that Jina's translanguaging was to elaborate on the particular topic using the language that she was familiar with.

Excerpt 3. Elaborating on a science concept through translanguaging

$\mathrm{T}$ : 학교에서 science 시간에는 뭐 배워? [What do you learn during the science class in your American school?]

2. Jina: 저는 몸 [I learned about the body.]

3. T: 몸? 사람 몸에 대해? 뭐 배웠는지 기억나? [Body? About human body? Do you remember what you have learned about?]

Jina: Um... about what's inside. About brain, heart, lung, and spinal cord. And function of our brain...

iv. Inserting words that are habitually used in a particular language. It was revealed that the students sometimes translanguaged terms that they used habitually at that moment they were speaking in the other language. Excerpt 4 includes translanguaging examples by the three students when they inserted terms that are habitually used in a particular language. In line 1, Mino translanguaged when he referred to his family members in Korean while speaking in English. During the interview, Mino explained that he always referred to his family members in Korean even when he spoke in English: "I think I always say mom, dad, and sister because I have called them that way since I was very young." Similarly, in line 2, Bomi referred to her teacher "선생님 (teacher)" while speaking in English. In Korea, the term
“선생님” is always used to refer to a teacher instead of using his/her last name. The referent indicates a way of showing respect in Korean. Since the term is commonly used at the Korean HL school when referring to a teacher by other teachers or parents, Bomi appeared to be more familiar with referring to the teacher in Korean.

On the other hand, Jina's example in line 3 displays when she inserted the English word "recess" in her Korean speech. Since Jina attended American school weekdays, the term recess is often used in English in her American school context. During the interview, Jina stated that "Sometimes I prefer speaking in English for some words, such as the words that I often use in English." The findings indicate that the students' translanguaging occurred as they chose the words from the language that they habitually used on a daily basis.

Excerpt 4. Translanguaging for habitually used words.

Mino: My family...um.. 우리 엄마, 아빠, 언니 went to the Disney World last month. [My family... um... my mom, dad, and sister went to the Disney World last month].

Bomi: 선생님, are we going to read that book today? [Teacher, are we going to read that book today?].

Jina: 근데 우리 오늘 recess 언제 해요? [When do we have recess today?].

\subsection{Students' Translanguaging for Directive Functions}

The students' translanguaging for directive function appeared in 201 utterances out of 1012 utterances (19.86\%), which is the second largest number followed by referential function. The students' translanguaging was analyzed as a directive in the following four functions: (a) building intimate relationships with others, (b) persuading others, (c) requesting information, and (d) attracting others' attention.

$i$. Building intimate relationships with peers. The students' translanguaging was often observed during their play. Excerpt 5 displays Jina's translanguaging when she was playing a card game with an English-dominant child, Narae, who did not participate in this study. While they were playing it using English, the teacher interrupted and asked them a question in Korean (line 1). Jina responded to the teacher in the same language, Korean (line 2), but she translanguaged into English when her audience changed to Narae (line 3). It appears that Jina purposefully switched her language in order to position herself as English proficient for her peer and resumed the card game with her, whose dominant language was English. In this example, Jina's translanguaging helped her build intimate relationships with her peer by sharing the same language.

Excerpt 5. Building an intimate relationship through translanguaging

1. T: 지나랑 나래랑 카드게임 하는 거예요? [Are you two playing the card game?]

2. Jina: 네, 근데 우리 다른 게임 해요. [Yes, but we are playing a different card game.]

3. Jina: (to Narae) Okay, Narae. Let's do it. Now you got a seven.

ii. Persuading others. The students' translanguaging for the directive function was detected when they tried to 
persuade others. Excerpt 6 shows an example that includes Bomi's translanguaging when she was persuading the teacher. In line 1, Bomi suggested that the class participate in the Korean game "The rose of Sharon blooms again" in the outdoor playground of the school during recess. As shown, Bomi spoke in English to the class, but in line 2, she translanguaged into Korean to ask for permission from the teacher. Bomi's following statement, "It is not too cold outside today," indicates that she was persuading the teacher by providing an acceptable reason. In addition, her use of the word "please" indicates that it was her polite request.

Excerpt 6. Persuading the teacher through translanguaging

Bomi: (to class) Why don't we play it outside?

Bomi: (to teacher) 선생님, 우리 outdoor play 해도 돼요? 제발요... 밖에 별로 안 추워요

오늘. [Teacher, can we do the outdoor play? Please... It is not too cold outside today.]

iii. Requesting information. The students' employment of translanguaging was also found when they requested information. Excerpt 7 shows an example of Mino's translanguaing when he asked a question to the teacher for new information. In line 1, Mino used English to explain a science concept that he had learned about in his American school. Listening to the information that Mino provided, Jina asked him a question in English (line 2), and their conversation continued in English until line 3. Yet, in line 4, Mino translanguaged into Korean in order to ask a question to the teacher to request information for the word "camouflage" in Korean.

Excerpt 7. Requesting information to the teacher using translanguaing

Mino: ...monarch butterfly is one type of butterfly. It is poisonous.... They [monarchybutterflies butterflies] warn themselves.

Jina: Is it like um... camouflage?

Mino: Yes! They use camouflage!

Mino: 선생님, "Camouflage"가 한국말로 무예요? [Teacher, how do we say "camouflage" in Korean?]

iv. Attracting others' attention. Another directive function from the students' translanguaging was discovered when they attracted others' attention. Excerpt 8 displays Mino's translanguaging example when he attracted his classmates' attentions by switching his language from Korean to English. Mino responded to the teacher in Korean (line 2) when the teacher complimented Jina's drawing (line 1), but he switched his language to English to draw his classmates' attention (line 3).

Excerpt 8. Attracting peers' attention

$\mathrm{T}$ : 여기 지나가 그린 것 좀 봐. 멋지지? [Look at Jina's drawing. Isn't it really great?]

Mino: 와, 진짜 잘했어요. [Wow, it is really great.]

Mino: (loudly, to class) Look at this, guys. This is amazing.

\subsection{Students' Translanguaging for Expressive Functions}

The students occasionally engaged in translanguaging for an expressive function (107 out of 1012 utterances; 10.57\%).
This function was analyzed when the students expressed their emotions and feelings as well as when they expressed their bilingual identity.

i. Expressing emotions and feelings. The close analysis further revealed that the students sometimes expressed their emotions or feelings through inner speech, and their selfdirected talk showed evidence of translanguaging. Excerpt 9 displays when Mino engaged in his self-talk during the conversation with the teacher. Mino used Korean when he spoke to the teacher (line 1), but he switched his language to English when he talked to himself (line 2). His self-talk included his straightforward and honest feeling as his audience was changed from the teacher to himself.

Excerpt 9. Expressing personal emotion through inner speech

Mino: (to teacher) 선생님, 우리 간식 언제 먹어요? 저 너무 배고파요. [Teacher, when do we have our snack time? I am so hungry.]

Mino: (to himself) I am super hungry now. I want to eat pizza.

ii. Expressing bilingual identity. The students' translanguaging revealed that they flexibly moved across the languages to express their bilingual identities. Excerpt 10 provides an example of how Bomi expressed her bilingual identity through translanguaging. In line 1, Bomi described in Korean how difficult it had been for her to attend a school in Korea. The teacher responded in Korean to praise Bomi's English (line 2) to which Bomi translanguaged and replied in English (line 3). Her translanguaging into English indicates that she had reacted in the language for which she was given a compliment, suggesting that she was conveying her identity as a bilingual.

Excerpt 10. Expression of bilingual identity through translanguaging

Bomi: 친구들이 laugh at me 했어, 나 한국말 잘못해서 [My classmates laugh [ed] at me because I didn't speak Korean well.]

$\mathrm{T}$ : 그런데 보미는 영어 잘하잖아. 그럼 영어 알려주고 한국말 배우면 되지. [But you are good at English. Then, you could teach them English and learn Korean from them.]

Bomi: Yes, I am good at English! I teach my friend in my class.

\subsection{Students' Translanguaging for Metalinguistic Functions}

The students' translanguaging for a metalinguistic function was infrequently detected (72 out of 1012 utterances; $7.11 \%$ ). The metalinguistic function was identified in the following three cases: (a) clarifying own's understanding, comparing languages, and (c) using metaphors.

$i$. Clarifying own's understanding. The students sometimes clarified their understanding by utilizing translanguaging. Excerpt 11 shows Bomi's use of translanguaging when she wanted to check her understanding of her unknown Korean word by using English. In line 1, the teacher explained about the story from the book that the class read, and Bomi asked a question about the Koran word ("귀한" [invaluable]) that she did not know in Korean (line 2). After the teacher answered 
to Bomi by providing the synonyms in Korean (line 3), Bomi translanguaged into English to ask a question and check whether the Korean words that the teacher provided were the same as what she knew in English (line 4). The example shows that Bomi translanguaged to find an English equivalency to the unknown Korean word in order to clarify her understanding.

Excerpt 11. Clarifying her understanding using translanguaging

$\mathrm{T}$ : 옛날에는 이게 매우 귀한 음식이라 임금님이 드셨던 거야. [In the past, this isinvaluable invaluable food that the king only can eat.]

Bomi: 귀한이 모야? [what is invaluable?]

$\mathrm{T}$ : 소중한, 비싼 그런 말이야. [It means precious or expensive.]

Bomi: Is it like precious?

ii. Comparing languages. The students engaged in translanguaging practices when they compared the languages that they spoke. The following excerpt (Excerpt 12) illustrates how Bomi and Jina utilized their metalinguistic awareness to compare English and Korean by applying what they knew about speaking in both languages. In line 1, Bomi translanguaged to point out the specific language feature from English-intonations-to compare the two languages that she knew. Jina agreed with what Bomi said, but she further addressed the unique language feature in Korean that has sentence - final intonation at the end of an interrogative sentence (line 2). The two students' statements, which include their use of translanguaging for the particular language features, suggest that they understood the differences between the two languages and further applied their linguistic knowledge to compare their two languages.

Excerpt 12. Comparing different linguistic features between two languages.

Bomi: 영어는 나 말할 때 up and down intonation 있는데, 한국말은 없어요.

[English has up and down intonation when I speak, but Korean does not have it].

Jina: 맞아요, 한국말은 flat 해요. 근데 question 할 때는 ending tone 올려요. [Yes, Korean is a flat language. But, when we ask a question, we need to rise the tone at the ending.]

iii. Using metaphors. The students occasionally used metaphors through translanguaging. Excerpt 13 illustrates when Mino used a metaphor by switching his language into English. The school provided Easter candies to each classroom, and the teacher asked the class a question about how many candies they can equally have (line 1). Yuna, a student who did not participate in this study, provided an answer in Korean rapidly by dividing and calculating the numbers (line 2). Mino responded to Yuna in Korean about her fast division calculation, and then he translanguaged into English to describe Yuna's intelligence by using a metaphor (line 3).

Excerpt 13. Using a metaphor through translanguaging $\mathrm{T}$ : 여기 사탕 17 개 있는데, 우리 반 5 명 이지. 그럼 몇 개씩 가지면 될까? [ We have 17 candies here. And there are
5 people in our class. How many candies can you all get?]

Yuna: We all can have three, that's 15 , so two people actually can have four.

Mino: 와, 엄청 빨라. [Wow, you are so fast]. Your brain is a computer.

\subsection{Students' Translanguaging for Poetic Functions}

Throughout the data, the students' translanguaging for a poetic function was rarely discovered (16 out of 1012 utterances; $1.58 \%$ ) since it was recognized only the case when the students were adding a sense of humor in their speech. Only two out of the three students (Mino and Bomi) translanguaged for this function by making jokes or exaggerating their statements.

Adding a sense of humor. Excerpt 14 illustrates an example by Mino when he was making a joke using translanguaging. Mino began to retell the story of the Korean folktale "Brother and Sister who Became Sun and Moon" in Korean (line 1), but he switched his language into English when he provided the reason why the tiger (the character from the book) could not climb the tree (line 2). Mino's statement in English was not accurate based on the story in the book. His following statement, "I am kidding," and his nonverbal communication-laughing-indicate that he was trying to make fun rather than transmitting correct information. Mino seemed to purposefully choose English as he was playing with language to make a joke by exaggerating the story, which suggests that his translanguaging functioned for adding a sense of humor.

Excerpt 14. Making a joke to exaggerate the story.

Mino: ...아이들이 도망가고 나무로 올라갔는데 호랑이가 못 올라갔어 왜냐하면 [The children ran away and climbed the tree, but the tiger could not climb the tree because...]

Mino: $\mathrm{He}$ is so fat, way too fat. $\mathrm{He}$ is 10,000 pounds (laugh). I am kidding.

\section{Discussion and Conclusion}

This study employed qualitative discourse analysis methods to investigate how three first-grade Korean bilingual students engaged in translanguaging practices over 14 weeks in a Korean HL classroom in the U. S. The participating students attended all-English schools during the week, were exposed to Korean at home, and attended a Korean HL School on Saturdays. Since the students attended U. S. classrooms taught only in English, the students believed that they became more fluent in English than Korean and identified themselves as English dominant speakers. Accordingly, engaging in translanguaging while speaking is considered as a natural phenomenon among the students as they were developing their bilingualism through everyday translanguaging practices [6]. As Wei called for research on the everyday translanguaging practices of young bilingual students, this study aimed to seek the functions of the students' translanguaging when they communicated at a Korean HL school. 
Based on Jakobson's [1] model on communicative functions of language, the emerged functional categories of the students' translanguaging across languages were found to serve as an expressive, directive, referential, metalinguistic, and poetic. Among the five functional categories, the students' translanguaging for the referential function was recorded as the highest $(60.86 \%)$, followed by directive (19.86\%), expressive $(10.57 \%)$, metalinguistic $(7.11 \%)$, and poetic $(1.58 \%)$ functions.

The close analysis revealed that 14 different subsidiary functions were found under the five functional categories. For instance, the students' translanguaging for the referential function was observed when they switched languages to maintain or facilitate the conversation, to deliver accurate meanings, to elaborate, and to incorporate habitually used terms or referents. It was found that more than half of the students' translanguaging under the referential function (312 turns out of the total of 616 referential turns) were detected when they borrowed lexical items from English as they did not know corresponding words in Korean. With this finding, it is plausible to assume that the students had a lack of knowledge in the target language (Korean); accordingly, they filled the lexical gap by borrowing their linguistic knowledge from their dominant language (English) in order to avoid deficiency in communication. Indeed, in earlier study, Eldridge [31] discovered that one of the most common functions of code-switching by learners in a high school ESL classroom was "floor holding" (p. 305) as they filled the gaps with native language use while communicating in a target language because of their lack of fluency in the target language. However, possible explanations for the current first-graders' switching might be that they were young emergent bilingual students, who still were developing their bilingualism; thus, their translanguaging appeared to serve for continuity in speech instead of encountering interference in the target language as a defensive mechanism. In this respect, translanguaging appears to help them maintain and even facilitate their conversation without eschewing deficiency in communication.

The students' translanguaging for the directive function was observed when they switched languages to build intimate relationships, to persuade others, to request information, and to attract others' attention. Particularly, the students' translanguaging functioned for building intimacy when they switched into the same language that their interlocutors spoke. The students exemplified what [32] called "code alignment," which explains that bilinguals consider their interlocutors" language use and that their language choice was influenced by their interlocutors. Past studies found that bilinguals tend to switch their languages for their group identification, solidarity, and intimacy [33, 34]. Correspondingly, the current students' translanguaging, which conformed to a principle of code alignment with their interlocutors, indicates that translanguaging appeared to work as a bridge that builds high intimacy in their relationship.

The students' translanguaging for the expressive function occurred when they expressed their bilingual identities and personal emotions/feelings. It was interesting to find that the students sometimes expressed their emotions or feelings through inner speech. Their self-directed dialogues indicated that they engaged in the process of internalization as they moved from interpersonal dialogues to intrapersonal speech to himself [35]. This form of internalized and self-directed dialogue, which involved translanguaging, is similar to the finding described by Martinez-Roldan [36]. One of the Spanish-English bilingual students in her study used Spanish when reading and discussing a book with the teacher but used English when talking and making comments to himself.

The students' metalinguistic function of translanguaging includes when they were 1) clarifying their understanding, 2) comparing languages, and 3) using metaphors. One of the translanguaging examples for the metalinguistic function was discovered when the students compared English and Korean by applying what they knew about both languages. The finding complies with Song's [37] result that the students in her study identified different phonetic systems in both languages and were able to manipulate the different sentence structures of their two languages. Lastly, the poetic function of translanguaging was intermittently discovered by the two students (Mino and Bomi) when they added a sense of humor as they were making jokes through translanguaging. Similar to the Spanish-English bilingual students in Creese and Blackledge's [14] and Hopewell and Abril-Gonzalez's [38] studies, the two first graders in this study showed that they could regulate their choice of languages to make a joke as a metalinguistically cognizant bilingual.

Consistent with Christoffersen's [39] finding that K-2 Spanish-English students in a dual language program differentiated their functional use of translanguaging by language, the first graders in this study also utilized different languages according to their different purposes. For example, the students' translanguaging were mostly found in English turns when elaborating one's ideas, using metaphors, and making jokes, whereas, their translanguaging were found in Korean turns when they inserted words that are culturallyrelated referents to express affection (to family members). This finding ties in Hopewell and Abril-Gonzalez's [38] study. The Spanish bilingual students in their study showed that they always used Spanish when they referred to their family members. Hopewell and Abril-Gonzalez pointed out that the students' use of home language to refer to their family members "expressed an intimacy and a particular closeness of relationship" (p. 114) that might not have been reflected if they used them in English. The other times when the students employed translanguaging into Korean was when their interlocutor became the teacher. It was shown that the students switched their language into Korean when asking for permission and requesting information to the teacher in order to show respect. The findings imply that the students' language choice was determined not only based on different purposes but also according to their different interlocutors. 


\section{Implications and Directions for Future Research}

Throughout the students' translanguaging data, which showed 14 different translanguaging functions under the five categories (referential, directive, expressive, metalinguistic, and poetic), it was revealed that the students' translanguaging was not accidental or deficient, but they were sophisticated, systematic, and purposeful. As Wei [6] argued that bilinguals do not think unilingually even when they are in a monolingual mode, the first-grade bilingual students' translanguaging practices did not indicate that they were thinking monolingually or separately in each language. Instead, the students were employing their integrated and unitary linguistic resources to communicate, make meaning, share experiences, and transmit knowledge, which exhibits the fluid and dynamic nature of their translanguaging.

The findings showed that engaging in translanguaging when communicating even in a monoglossic classroom setting (such as an HL classroom like this study) is considered as a natural phenomenon among bilingual students as they were activating and developing their bilingualism through everyday translanguaging practices [6]. The findings provide implications for teachers of bilingual learners that providing spaces for translanguaging can assist students in developing their bilingualism as they will have opportunities to utilize linguistic resources available to them. Teachers also should aware that encouraging translanguaging further improves the students' class participation [8]. As Wei [40] defined translanguaing space as "a space for the act of translanguaging as well as a space created through translanguaging" (p. 1234), it is important to note that bilinguals' learning and participation can be maximized when they are enabled to draw from all their multiple languages and linguistic repertoires. In other words, educators should keep in mind that bilingual students will be able to actively engage in learning and meaningfully participate in class activities when they have access to their entire linguistic repertoires.

The findings of this study are congruent with previous research on emergent bilingual students' translanguaging practices in classroom contexts. Yet, the current study further validates that bilinguals who were developing two nonrelated languages were able to utilize their entire linguistic resources to communicate strategically in the monoglossic classroom where translanguaging was not pervasive. Still, the study had several limitations. First, the study included a small number of students (three students) for a relatively short period of time (14 weeks). Thus, the functions for the students' translanguaging might be limited and might not have shown their translanguaging trajectory over the school year. In addition, the study did not focus on the teacher's translanguaging. Indeed, the teachers' use of translanguaging as an instructional strategy might have prompted or influenced the students' translanguaging in the HL class. Finally, I did not examine the students' translanguaging practices in their homes or in their American schools taught in English. The students' translanguaging patterns and functions might vary according to the setting and the language norms of each setting [41]. Additional researchers need to investigate the translanguaging practices of bilingual students from different language groups and in different instructional settings, including home contexts over a period of time to seek whether their translanguaging practices document the similar functions from this study.

\section{References}

[1] Jakobson, R. (1960). Closing statement: Linguistics and poetics. In A. S. Thomas (Ed.), Style in language (pp. 350377). Cambridge, MA: The MIT Press.

[2] Lindholm-Leary, K. J. (2001). Dual language education. Clevedon, UK: Multilingual Matters. Martin-Beltran, M. (2010). The two-way language bridge: Co-constructing bilingual language learning opportunities. The Modern Language Journal, 94 (2), 254-277.

[3] García, O. (2011). Educating New York's bilingual children: Constructing a future from the past. Internatioanl Journal of Bilingual Education and Bilingualism, 14, 133-153.

[4] Genesee, F. (2008). Bilingual first language acquisition: Evidence from Montreal. Diversite urbaine, 9-26.

[5] García, O. (2009). Bilingual education in the 21st century: A global perspective. West Sussex, UK: Wiley-Blackwell.

[6] Wei, L. (2018). Translanguaging as a practical theory of language. Applied Linguistics, 39 (1), 9-30.

[7] Bailey, B. (2012). Heteroglossia. In The Routledge handbook of multilingualism, ed. M. Martin-Jones, A. Blackledge, and A. Creese, 499-507. London, UK: Routledge.

[8] García, O., \& Wei, L. (2014). Translanguaging: Language, bilingualism and education. Basingstoke, UK: Palgrave Macmillan.

[9] Lewis, G., Jones, B., \& Baker, C. (2012). Translanguaging: Developing its conceptualization and contextualization. Educational Research and Evaluation, 18, 655-670.

[10] Bauer, E. B., Presiado, V., \& Colomer, S. (2017). Writing through partnership: Fostering translanguaging in children who are emergent bilinguals. Journal of Literacy Research, 49 (1), 10-37.

[11] Durán, L., \& Palmer, D. (2014). Pluralist discourses of bilingualism and translanguaging talk in classrooms. Journal of Early Childhood Literacy, 14, 367-388.

[12] Nam, K. M. (2017). How young children make sense of two different writing systems: Korean written in the Hangul alphabet, and English written in the Roman alphabet. Journal of Early Childhood Literacy, 18 (4), 490-517.

[13] Bakhtin, M. M. (1981). The dialogic imagination: Four essays. (M. Holquist, Ed.; C. Emerson \& M. Holquist, Trans.). Austin: University of Texas Press.

[14] Creese, A., \& Blackledge, A. (2010). Translanguaging in the bilingual classroom: A pedagogy for teaching and learning. The Modern Language Journal, 94, 103-115. 
[15] Canagarajah, A. S. (2011). Codemeshing in academic writing: Identifying teachable strategies of translanguaging. The Modern Language Journal, 95, 401-417.

[16] Velasco, P., \& García, O. (2014). Translanguaging and the writing of bilingual learners. Bilingual Research Journal: The Journal of the National Association of Bilingual Education, 37 (1), 6-23.

[17] Gravelle, M. (1996). Supporting bilingual learners in schools. Stoke-on-Trent, UK: Trentham.

[18] Soltero-González, L., \& Butvilofsky, S. (2016). The early Spanish and English writing development of simultaneous bilingual preschoolers, Journal of Early Childhood Literacy, 16 (4), 473-497.

[19] Appel, R., \& Muysken, P. (1987). Language Contact and Bilingualism. Amsterdam: Amsterdam University Press.

[20] Grosjean, F. (1982). Life with Two Languages: An Introduction to Bilingualism. Cambridge, MA: Harvard University Press.

[21] Malik, L. (1994). Socio-linguistics: A study of code-switching. New Delhi, ND: Anmol Publications Pvt. Ltd.

[22] Shay, O. (2015). To switch or not to switch: Code-switching in a multilingual country. Social and Behavioral Sciences, 209, 462-469.

[23] Kramsch, C. \& Whiteside, A. (2007). Three fundamental concepts in SLA and their relevance in multilingual contexts. Modern Language Journal, 91, 905-920.

[24] Gort, M. (2012). Code-switching patterns in the writingrelated talk of young emergent bilin- guals. Journal of Literacy Research, 44 (1), 45-75.

[25] Tribus, A. (2017). "The Communicative Functions of Language: An Exploration of Roman Jakobson's Theory in TESOL". MA TESOL Collection. 723.

[26] Mertens, D. M. (2015). Research and evaluation in education and psychology: Integrating diversity with quantitative, qualitative, and mixed methods (4th ed.). Thousand Oaks, CA: Sage.

[27] Gee, J. P. (2012). Social linguistics and literacies: Ideology in discourses (4th ed.). London, UK: Routledge.

[28] Saville-Troike, M. (2008). The ethnography of communication: An introduction (4th ed.). Malden, MA: Blackwell. Sayer, P. (2013). Translanguaging, TexMex, and bilingual pedagogy: Emergent bilinguals learning through the vernacular. TESOL Quarterly, 47 (1), 63-88.
[29] Bogdan, R., \& Biklen, S. (2003). Qualitative research for education: An introduction to theories and methods. New York: Allyn and Bacon.

[30] Agar, M. (1996). The professional stranger: An informal introduction to ethnography. San Diego, CA: Academic Press.

[31] Eldridge, J. (1996). Code-switching in a Turkish secondary school, English Language Teaching Journal, 50 (4), p. 303311. International perspectives on bilingual education: Policy, practice, controversy. Charlotte, NC: Information Age Publishing. (pp. 69-93).

[32] Sayer, P. (2013). Translanguaging, TexMex, and bilingual pedagogy: Emergent bilingual learning through the vernacular. TESOL Quarterly, 47 (1), 63-88.

[33] Creese, A. (2018). Translanguaging and translation: the construction of social difference across city spaces. International Journal of Bilingual Education and Bilingualism, 21 (7), p. 841-852.

[34] García, O., \& Leiva, C. (2013). Theorizing and Enacting Translanguaging for Social Justice. In A. Blackledge., \& A. Creese (Eds.). Heteroglossia as Practice and Pedagogy (pp 199-216). New York, NY: Springer.

[35] Vygotsky, L. S. (1978). Mind in society: The development of higher psychological processes. Cambridge, MA: Harvard University Press.

[36] Martínez-Roldán, C. M. (2015). Translanguaging practices as mobilization of linguistic resources in a Spanish/English bilingual after-school program: An analysis of contradictions. International Multilingual Research Journal, 9 (1), 43- 58.

[37] Song, K. (2016). "Okay, I will say in Korean and then in American": Translanguaging practices in bilingual homes. Journal of Early Childhood Literacy, 16 (1), 84-106.

[38] Hopewell, S., \& Abril-Gonzalez, P. (2019). ¿Por qué estamos code-switching? Understanding language use in a secondgrade classroom, Bilingual Research Journal, 42 (1), 105-120.

[39] Christoffersen, K. (2017). What Students Do with Words: Language Use and Communicative Function in Full and Partial Immersion Classrooms, NABE Journal of Research and Practice 8 (1), 92-110.

[40] Wei, L. (2011). Moment Analysis and translanguaging space: Discursive construction of identities by multilingual Chinese youth of Britain. Journal of Pragmatics, 43, 1222-1235.

[41] Lee, C., \& García, E. G. (2020). Unpacking the oral translanguaging practices of Korean-American first graders. Bilingual Research Journal, 43 (1), 32-49. 